\title{
Pengaruh Umur Panen Terhadap Aktivitas Antioksidan dan Kualitas Buah Okra Merah (Abelmoschus esculentus (L.) Moench)
}

\section{(Effect of Harvest Age on Antioxidant Activity and Quality of Red Okra's Fruit (Abelmoschus esculentus (L.) Moench))}

\author{
Ah. Maftuh Hafidh Zuhdi $^{1}{ }^{*}$, Sinar Suryawati ${ }^{1}$, dan Achmad Djunaidi ${ }^{1}$ \\ ${ }^{\mathbf{1}}$ Program Studi Agroteknologi, Fakultas Pertanian, Universitas Trunojoyo Madura \\ Jalan Raya Telang, Telang, Bangkalan, Kamal, Madura, Jawa Timur 69162 \\ *Email korespondensi : zuhdiarewa@gmail.com
}

Diterima 25 Februari 2019/Disetujui 01 Maret 2019

\begin{abstract}
Okra fruit (Abelmoschus esculentus (L.) Moench) is a vegetable that contains polyphenol, carotenoid, flavonoid, and vitamin. The contains of okra fruit can be antioxidants. One of the Antioxidants contens is affected by the harvesting age. Late harvesting si affected for fruit texture, so it will determine that okra fruit be able consumed as a vegetable. This research intends to knowing the effect of different harvest age on antioxidant activity and knowing the best harvest age on the harvest of okra fruit for a vegetable consumption. This research used non-practical complete randomized design (CRD) with 8 treatments, specifically P1 (harvesting three days after flowering), P2 (harvesting four days after flowering), P3 (harvesting five days after flowering), P4 (harvesting six days after flowering), P5 (harvesting seven days after flowering), P6 (harvesting eight days after flowering), P8 (harvesting ten days after flowering). Harvesting six days after flowering for red okra is the best treatment for vegetable consumption by total antioxidant activity value $87.05 \%$, fruit length $12.22 \mathrm{~cm} /$ fruit, fruit diameter $1.19 \mathrm{~cm} /$ fruit, fruit wet weight $18.61 \mathrm{~g} /$ fruit, fruit dry weight $1.17 \mathrm{~g} /$ fruit, fruit water content $90.87 \% /$ rruit, fruit color $(\mathrm{L}$ 13.90; a 4.30; $b$ 15.48), and fruit texture (hardness $362.25 \mathrm{~g} /$ fruit, fracturabilty $438.93 \mathrm{~g} /$ fruit, chewiness 5.47).
\end{abstract}

Keyword : Abelmoschus esculentus (L.) Moench, antioxidants, fruit quality, harvesting age.

\begin{abstract}
ABSTRAK
Buah okra (Abelmoschus esculentus (L.) Moench) merupakan sayuran yang memiliki kandungan senyawa polifenol, karotenoid, flvonoid, dan vitamin yang dapat bertindak sebagai antioksidan. Kandungan senyawa antioksidan buah, salah satunya dipengaruhi oleh umur panen. Umur panen yang terlambat juga mempengaruhi tekstur buah sehingga akan menentukan layak tidaknya buah okra dikonsumsi sebagai sayur. Penelitian ini bertujuan untuk mengetahui pengaruh umur panen yang berbeda terhadap aktivitas antioksidan dan mengetahui umur panen buah okra terbaik untuk konsumsi sayur. Penelitian ini mengunakan rancangan acak lengkap dengan 8 perlakuan umur panen, yaitu P1 (panen 3 hari setelah bunga mekar), P2 (panen 4 hari setelah bunga mekar), P3 (panen 5 hari setelah bunga mekar), P4 (panen 6 hari setelah bunga mekar), P5 (panen 7 hari setelah bunga mekar), P6 (panen 8 hari setelah bunga mekar), P7 (panen 9 hari setelah bunga mekar), P8 (panen 10 hari setelah bunga mekar). Umur panen buah okra merah 6 hari setelah bunga mekar merupakan perlakuan terbaik untuk sayur dengan nilai aktivitas antioksidan total 87.05\%, panjang buah $12.22 \mathrm{~cm} / \mathrm{buah}$, diameter buah $1.19 \mathrm{~cm} /$ buah, bobot basah buah $18.61 \mathrm{~g} /$ buah, bobot kering buah $1.17 \mathrm{~g} / \mathrm{buah}$, kadar air buah 90.87\%/buah, warna buah (L 13.90; a 4.30; b 15.48), dan tekstur buah (kekerasan $362.25 \mathrm{~g} /$ buah; daya patah $438.93 \mathrm{~g} /$ buah; kealotan 5.47).
\end{abstract}

Kata kunci : Abelmoschus esculentus (L.) Moench, antioksidan, kualitas buah, umur panen.

\section{PENDAHULUAN}

Seiring dengan meningkatnya kesadaran masyarakat akan pentingnya kesehatan dalam pencegahan atau penyembuhan penyakit maka pangan yang dikonsumsi diharapkan tidak hanya punya rasa yang lezat dan mengenyangkan, tetapi juga mempunyai manfaat bagi kesehatan.

Sayuran merupakan salah satu komoditas pangan yang mempunyai senyawa atau komponen bioaktif yang bermanfaat bagi kesehatan yaitu serat pangan, vitamin, mineral, asam lemak, senyawa antioksidan, dan senyawa fitokimia lainya (Winarti, 2016). Salah satu jenis sayuran 
yang bermanfaat bagi kesehatan adalah buah okra merah (Abelmoschus esculentus (L.) Moench).

Tanaman okra (Abelmoschus esculentus (L.) Moench) termasuk dalam famili Malvaceae. Secara umum yang banyak dikenal adalah jenis okra hijau dan okra merah. Penamaan tersebut berdasarkan dari warna buah okra (Ikrarwati dan Rokhmanah, 2016). Buah tanaman okra biasa dikonsumsi pada saat masih segar dan masih muda, apabila waktu pemanenanya terlambat atau buah terlalu tua, buah okra akan keras, karena serat kasarnya akan meningkat dan tidak layak konsumsi.

Normalnya umur panen buah okra adalah 5 sampai 10 hari setelah bunga mekar (Adetuyi et al, 2008). Namun perbedaan spesies okra juga akan mempengaruhi waktu panen buahnya. Menurut Olivera et al. (2012) varietas tanaman okra lokal dari Brunos Aires memiliki waktu panen buah yang lebih singkat dibandingkan varietas okra, Emerald, Clemson, Spineless, dan Annie Oakley II, namun varietas okra lokal Brunos Aires memiliki ukuran buah yang lebih kecil dari pada ke empat varietas okra lainnya.

Menurut United States Department of Agriculture (2016), buah okra memiliki kandungan serat, kandungan senyawa polifenol, karotenoid, flvonoid, vitamin, dan mineral yang dapat bertindak sebagai antioksidan.

Antioksidan merupakan senyawa yang dapat menghambat reaksi oksidasi, dengan cara mengikat radikal bebas. Menurut Sayuti dan Rina (2015) penelitian tentang antioksidan alami pada bahan pangan menjadi trend akhirakhir ini. Sementara itu, pilihan dan ketersediaan terhadap antioksidan alami masih terbatas. Aktivitas antioksidan merupakan kapasitas antioksidan yang langsung menjangkau radikal bebas yang dinyatakan dalam persen.

Aktivitas antioksidan buah, salah satunya dipengaruhi oleh umur panen. Menurut Hariani et al. (2012) pemanenan merupakan aspek yang erat hubungannya dengan fase pertumbuhan tanaman yang mencerminkan tingkat kematangan fisiologis bagian tanaman dan mempunyai hubungan yang kuat dengan produksi dan kandungan yang ada dalam tanaman umur panen juga akan mempengaruhi tektur buah. karena selama proses pematangan dan pemasakan buah akan terjadi perubahan biokimia, perubahan yang sering terjadi adalah perubahan pati menjadi glukosa, menurunnya kadar asam dan meningkatnya zat padat terlarut. Glukosa merupakan bahan dasar dari senyawa fitokimia atau metabolit sekunder yang berperan antara lain sebagai senyawa antioksidan. Selain perubahan biokimia, umur panen juga akan mempengarui perubahan warna, tekstur buah, ukuran, dan bentuk buah atau bagian tanaman.

Berdasarkan uraian diatas diduga umur panen yang berbeda akan mempengaruhi aktivitas antioksidan dari buah okra merah, sehingga perlu dilakukan penelitian tentang pengaruh umur panen terhadap aktivitas antioksidan dan kualitas buah okra merah (Abelmoschus esculentus (L.) Moench). Penelitian ini dilakukan untuk mengetahui pengaruh umur panen yang berbeda terhadap aktivitas dan kualitas buah okra merah dan mengetahui umur panen buah okra terbaik untuk konsumsi sayur.

\section{BAHAN DAN METODE}

Penelitian ini dilakukan di Kebun Percobaan Program Studi Agroteknologi Fakultas Pertanian Universitas Trunojoyo Madura yang terletak di Desa Telang Kecamatan Kamal, Kabupaten Bangkalan Madura, dengan ketinggian tempat \pm 5 mdpl. Penelitian ini dilaksanakan pada bulan Desember hingga Februari 2018.

Bahan yang digunakan adalah tanah mediteran, pupuk kandang, arang sekam, decis, pupuk Urea, pupuk $\mathrm{KCl}$, DPPH (2,2-difenil-1-pikrilhidrazil), etanol 70\%, metanol $70 \%$ dan benih tanaman okra merah varietas Carmine Splender. Penelitian ini menggunakan rancangan acak lengkap (RAL) yang terdiri dari 8 perlakuan, yaitu: P1 (panen 3 hari setelah bunga mekar), P2 (panen 4 hari setelah bunga mekar), P3 (panen 5 hari setelah bunga mekar), P4 (panen 6 hari setelah bunga mekar), P5 (panen 7 hari setelah bunga mekar), P6 (panen 8 hari setelah bunga mekar), P7 (panen 9 hari setelah bunga mekar), dan P8 (panen 10 hari setelah bunga mekar).

Tahapan penenlitian meliputi pembibitan untuk mendapatkan bibit tanaman okra yang seragam, persiapan media tanam campuran tanah mediteran, pupuk kandang dan arang sekam dengan perbandingan 1:1:1, tranplating dilakukan pada bibit tanaman okra yang sudah berumur 10 hari setelah tanam dimasukan kedalam pot ukuran $35 \times 20 \mathrm{~cm}$, pemupukan dilakukan pada media dilakukan 14 hari setelah tanam menggunakan pupuk Urea dan $\mathrm{KCl}$, masing masing sebanyak $10 \mathrm{~g} /$ pot. Pemupukan susulan diberikan tiga dan enam minggu setelah tanam menggunakan Urea $10 \mathrm{~g} / \mathrm{pot}$, pemeliharaan meliputi penyiraman dan pengendalian hama penyakit, pemanena dilakukan sesuai perlakuan, analisis aktivitas antioksidan total dilakukan dengan metode DPPH dilakukan dengan sitem duplo.

Pengamatan dilakukan setelah buah okra merah dipanen, Variabel Pengamatan meliputi panjang buah, diameter buah, bobot basah buah, bobot kering buah, kadar air buah, tekstur buah, dan aktivitas antioksidan buah.

Data yang diperoleh dianalisis dengan mengunakan ANOVA, dan uji Beda Jarak Nyata Duncan (BJND) dengan taraf $5 \%$ apaila terdapat perbedaan antar perlakuan.

\section{HASIL DAN PEMBAHASAN}

\section{Panjang buah dan diameter buah}

Umur panen yang berbeda memberikan pergaruh nyata pada variabel pengamatan panjang buah, diameter buah, bobot basah buah, bobot kering buah, kadar air buah, kadar padatan buah, tekstur buah dan aktivitas antioksidan buah namun tidak berpengaruh nyata terhadap variabel pengamatan warna buah. Perbedaan buah okra akibat umur panen yang berbeda bisa dilihat pada Gambar 1. 


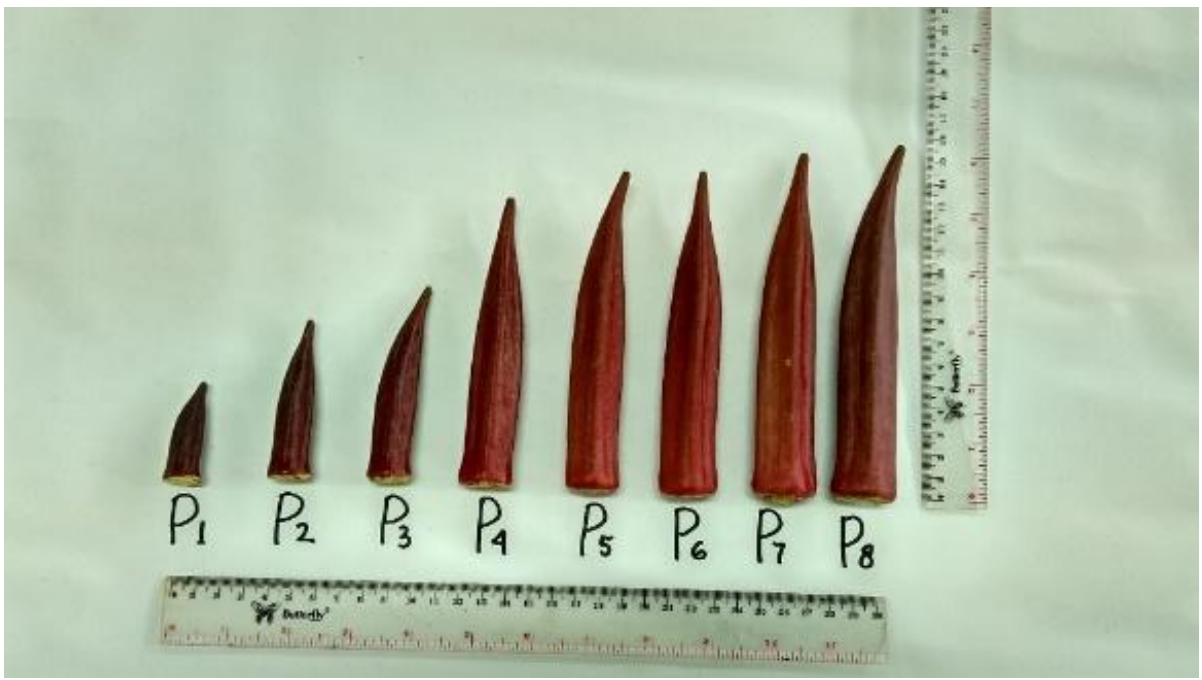

Gambar 1. buah okra merah pada berbagai umur panen.

Tabel 1. Rerata panjang buah okra $(\mathrm{cm})$ dan diameter buah okra $(\mathrm{cm})$.

\begin{tabular}{lcc}
\hline Umur Panen (HSBM) & Panjang Buah (cm/buah) & Diameter Buah $(\mathrm{cm} / \mathrm{buah})$ \\
\hline P1 (3 hari) & $4.20 \mathrm{f}$ & $1.20 \mathrm{f}$ \\
P2 (4 hari) & $6.39 \mathrm{e}$ & $1.39 \mathrm{e}$ \\
P3 (5 hari) & $9.38 \mathrm{~d}$ & $1.67 \mathrm{~d}$ \\
P4 (6 hari) & $12.22 \mathrm{c}$ & $1.91 \mathrm{c}$ \\
P5 (7 hari) & $14.04 \mathrm{~b}$ & $2.19 \mathrm{~b}$ \\
P6 (8 hari) & $14.45 \mathrm{ba}$ & $2.30 \mathrm{a}$ \\
P7 (9 hari) & $14.85 \mathrm{a}$ & $2.35 \mathrm{a}$ \\
P8 (10 hari) & $14.89 \mathrm{a}$ & $2.39 \mathrm{a}$ \\
\hline
\end{tabular}

Keterangan : HSBM (hari setelah bunga mekar). Angka - angka yang di ikuti huruf yang sama pada kolom yang sama tidak berbeda nyata uji Duncan 5\%.

Dapat dilihat pada Gambar 1 perbedaan buah okra akibat umur panen yang berbeda. Secara fisik terlihat bahawa perbedaan umur panen buah okra akan mempengaruhi ukuran buah meliputi panjang dan diameter buah yang terlihat pada Tabel 1 .

Pada variabel panjang buah, umur panen buah 10 hari setelah bunga mekar (P8) memiliki nilai paling tinggi tetapi tidak berbeda nyata dengan perlakuan P6 dan P7. pengamatan diameter buah pada umur panen 10 hari setelah bunga mekar (P8) memberikan nilai paling tinggi namun tidak berpengaruh nyata dengan perlakuan P8 dan P9. Hal ini sama seperti variabel panjang buah, dimana pada umur 3 hari setelah bunga mekar (P1) sampai 10 hari setelah bunga mekar (P8) buah okra mengalami

proses pembelahan dan pembesaran sel sehingga buah okra pada perlakuan P1 sampai P6 mengalami perubahan ukuran yakni pertumbuhan panjang buah yang terus bertambah cepat. Sedangkan pada perlakuan P6 sampai P8 buah okra diduga sudah masuk fase pendewasaan sel dan pematangan sehingga tidak terjadi perubahan ukuran yang signifikan.

Menurut Hidayat (2010) pada fase inisiasi buah sampai buah muda laju pertumbuhan panjang dan diameter buah semakin cepat dan pada fase buah muda menuju dewasa pertumbuhan panjang dan diameter buah akan semakin lambat. Hal ini dikarenakan panjang buah dan diameter buah termasuk perubahan visual buah terkait bentuk dan ukuran.

\section{Bobot Basah Buah dan Bobot Kering Buah}

Hasil analisis sidik ragam pada pada variabel pengamatan bobot basah buah dan bobot kering buah pada Tabel 2. Menunjukkan bahwa bobot basah buah pada umur panen 10 hari setelah (P8) memberikan nilai paling tinggi namun tidak berbeda nyata dengan perlakuan P7, bobot kering buah pada perlakuan P8 memberikan nilai bobot kering buah tertinggi namun tidak berpengaruh nyata denga perlakuan P7 hal ini sama seperti bobot basah buah dimana pada perlakuan P1 sampai P8 nilai bobot kering buah semakin meningkat.

Perlakuan P1 sampai P8 nilai bobot basah buah semakin meningkat hal ini dikarenakan panjang buah dan diameter buah pada perlakuan P1 sampai P8 nilai panjang dan diameter buah juga bertambah. Sehingga bobot basah buah juga ikut bertambah. 
Tabel 2. Rerata bobot basah buah okra (g/buah) dan bobot kering buah okra (g/buah)

\begin{tabular}{lcc}
\hline Umur Panen (HSBM) & Bobot Basah Buah (g/buah) & Bobot Kering Buah (g/buah) \\
\hline P1 (3 hari) & $3.05 \mathrm{f}$ & $0.36 \mathrm{e}$ \\
P2 (4 hari) & $5.77 \mathrm{f}$ & $0.59 \mathrm{ed}$ \\
P3 (5 hari) & $11.15 \mathrm{e}$ & $1.22 \mathrm{~cd}$ \\
P4 (6 hari) & $18.61 \mathrm{~d}$ & $1.71 \mathrm{c}$ \\
P5 (7 hari) & $26.30 \mathrm{c}$ & $3.64 \mathrm{~b}$ \\
P6 (8 hari) & $30.96 \mathrm{~b}$ & $4.33 \mathrm{~b}$ \\
P7 (9 hari) & $33.33 \mathrm{ba}$ & $5.65 \mathrm{a}$ \\
P8 (10 hari) & $34.59 \mathrm{a}$ & $5.68 \mathrm{a}$ \\
\hline
\end{tabular}

Keterangan : HSBM (hari setelah bunga mekar). Angka - angka yang di ikuti huruf yang sama pada kolom yang sama tidak berbeda nyata uji Duncan 5\%.

Tabel 3. Rerata kadar air buah okra (\%) akibat umur panen yang berbeda.

\begin{tabular}{cc}
\hline Umur Panen (HSBM) & Kadar Air Buah (\%) \\
\hline P1 (3 hari) & $88.12 \mathrm{cb}$ \\
P2 (4 hari) & $89.87 \mathrm{ba}$ \\
P3 (5 hari) & $88.93 \mathrm{ba}$ \\
P4 (6 hari) & $90.87 \mathrm{a}$ \\
P5 (7 hari) & $86.16 \mathrm{~cd}$ \\
P6 (8 hari) & $86.06 \mathrm{c}$ \\
P7 (9 hari) & $82.83 \mathrm{e}$ \\
P8 (10 hari) & $83.66 \mathrm{ed}$ \\
\hline
\end{tabular}

Keterangan : HSBM (hari setelah bunga mekar). Angka - angka yang di ikuti huruf yang sama pada kolom yang sama tidak berbeda nyata uji Duncan 5\%.

\section{Kadar air buah}

Penentuan nilai kadar air buah dilakukan dengan menggunakan metode oven. variebel pengamatan bobot basah buah dan bobot kering buah didapatkan nilai kadar air buah bisa di lihat pada Tabel 3. Kadar air buah pada perlakuan P4 memberikan nilai tertinggi sebesar 90.87\%. Pada perlakuan P1 sampai P4 kadar air semakin meningkat, kemudian pada perlakuan P4 sampai P8 nilai kadar air buah semakin menurun. Menurut hidayat (2010) pada fase inisiasi buah sampai buah muda, kadar air buah akan meningkat secara tajam dan pada fase buah muda menuju dewasa kadar air buah akan menurun drastis. Secara umum buah mememiliki kandungan komponen tertinggi yaitu air (6590\%) (Warsito et al. 2015). Menurut Nurhayati (2004) air terbentuk akibat adanya perombakan gula menjadi senyawa yang lebih sederhana dan pada saat yang sama akan terjadi penguapan air melalui lentisel. Perbedaan laju pembentukan air dalam jaringan dan laju penguapan akan menentukan kadar air dalam suatu bahan. Sehingga pada perlakuan P4 diduga laju pembentukan air masih lebih tinggi dibandingkan dengan laju penguapan, sehingga kadar air buah lebih tinggi daripada perlakuan lain.

\section{Tekstur Buah}

Variabel pengamatan tekstur buah ada 3 aspek yang di amati yaitu hardness, fracturability, dan chewiness. Bisa dilihat pada Tabel 4.

Tabel 4. Rerata hardness (g), fracturability (g) dan chewiness akibat umur panen yang berbeda.

\begin{tabular}{|c|c|c|c|c|c|}
\hline \multirow{2}{*}{$\begin{array}{l}\text { Umur Panen } \\
\text { (HSBM) }\end{array}$} & \multicolumn{5}{|c|}{ Tekstur Buah } \\
\hline & Hardness (ke & kerasan $)(g)$ & Fracturability (daya patah) (g) & Chewines & (kealotan) \\
\hline P1 (3 hari) & 249.17 & $\mathrm{e}$ & 555.63 dce & 2.29 & $\mathrm{~b}$ \\
\hline P2 (4 hari) & 268.10 & e & $515.39 \mathrm{de}$ & 3.34 & $\mathrm{~b}$ \\
\hline P3 (5 hari) & 376.83 & de & 596.81 dce & 4.25 & $\mathrm{~b}$ \\
\hline P4 (6 hari) & 362.25 & de & $438.93 \mathrm{e}$ & 5.47 & $\mathrm{~b}$ \\
\hline P5 (7 hari) & 483.06 & $\mathrm{~d}$ & $865.99 \mathrm{dcb}$ & 35.82 & $\mathrm{a}$ \\
\hline P6 (8 hari) & 760.18 & $\mathrm{c}$ & $959.69 \mathrm{cb}$ & 33.87 & $\mathrm{a}$ \\
\hline P7 (9 hari) & 1026.70 & $\mathrm{~b}$ & 1195.40 ba & 41.93 & $\mathrm{a}$ \\
\hline P8 (10 hari) & 1529.59 & $\mathrm{a}$ & $1376.51 \quad \mathrm{a}$ & 45.16 & $\mathrm{a}$ \\
\hline
\end{tabular}

Keterangan : HSBM (hari setelah bunga mekar). Angka - angka yang di ikuti huruf yang sama pada kolom yang sama tidak berbeda nyata uji Duncan $5 \%$. 
Pada umur panen 10 hari setelah bunga mekar (P8) mendapatkan nilai hardness tertinggi, dimana semakin lama umur panen buah okra akan menyebabkan nilai kekerasan yang meningkat. Menurut Womdim et al. (2009) buah okra yang dipanen lebih

dari tujuh hari setelah pembentukan buah memiliki kualitas yang rendah karena meningkatnya serat kasar dan berkurangnya lendir buah. Sehingga semakin lama umur panen makan serat kasar buah okra akan meningkat dan mengurangi kualitas dari buah okra. Menurut Maliluan et al. (2013), semakin tinggi kadar serat pangan maka semakin keras tekstur dari produk. kerapuhan).

Aspek selanjutnya yaitu fracturability (daya patah / Dari hasil yang di dapat nilai fracturability tertinggi didapat perlakuan P8 namun tidak berbeda nyata dengan perlakuan P7. Semakin lama umur panen nilai fracturability semakin tinggi. Namun pada perlakuan P4 memiliki nilai fracturability paling rendah walaupun tidak berbeda nyata dengan perlakuan P1, P2, dan P3, hal ini diduga terkait dengan variabel kadar air buah dimana pada perlakuan P4 memiliki kadar air tertinggi. Menurut Muchtadi et al. (2013) air di dalam sel akan mempengaruhi tekanan turgor sel jika air didalam sel bertambah melebihi keadaan normal maka sel akan pecah dan isi selna akan keluar sehingga keteguhan (kekersan) sel hilang. Oleh karena itu turgor berpengaruh terhadarp kekerasan sel sel parenkim dengan demikian juga berpengaruh terhadap tektur bahan. Sehingga buah okra dengan kadar air tinggi akan memiliki nilai fracturability yang rendah maka buah okra mudah dipatahkan.

Aspek selanjutnya yaitu chewiness (kealotan) Dari hasil yang di dapat nilai chewiness tertinggi di dapat pelakuan P8 namun tidak berbeda nyata dengan perlakuan P5, P6, dan P7. Semakin lama umur panen nilai chewiness akan semakin besar. Hal ini diduga karena semakin lama umur panen kadar serat kasar buah okra akan semakin meningkat dan kadar air cenderung menurun akibatnya buah semakin keras sehingga nilai chewiness juga semakin besar, maka energi yang dibutuhkan untuk mengunyah akan semakin besar seiring dengan lamanya umur panen buah okra merah.

\section{Warna Buah}

Variabel warna buah terdapat tiga aspek yang diamati yakni L (lightness) a (redness) dan (yellowness) yang bisa di lihat pada Tabel 5.

Tabel 5. Rerata warna buah okra (L,a,b)

\begin{tabular}{llcc}
\hline \multirow{2}{*}{ Umur Panen (HSBM) } & \multicolumn{3}{c}{ Warna Buah } \\
\cline { 2 - 4 } P1 (3 hari) & $(\mathrm{L})$ & $(\mathrm{a})$ & 18.10 \\
P2 (4 hari) & 12.95 & 5.53 & 18.70 \\
P3 (5 hari) & 12.93 & 5.30 & 15.48 \\
P4 (6 hari) & 13.90 & 5.38 & 15.48 \\
P5 (7 hari) & 13.90 & 4.30 & 17.35 \\
P6 (8 hari) & 13.90 & 5.10 & 18.35 \\
P7 (9 hari) & 13.63 & 5.55 & 17.45 \\
P8 (10 hari) & 13.53 & 7.15 & 17.35 \\
\hline
\end{tabular}

Keterangan : HSBM (hari setelah bunga mekar)

Tabel 6. Rerata aktivitas antioksidan total buah okra (\%)

\begin{tabular}{cc}
\hline Umur Panen (HSBM) & Aktivitas Antioksidan Total (\%) \\
\hline P1 (3 hari) & $61.99 \mathrm{~b}$ \\
P2 (4 hari) & $83.01 \mathrm{a}$ \\
P3 (5 hari) & $85.49 \mathrm{a}$ \\
P4 (6 hari) & $87.05 \mathrm{a}$ \\
P5 (7 hari) & $88.86 \mathrm{a}$ \\
P6 (8 hari) & $87.42 \mathrm{a}$ \\
P7 (9 hari) & $86.24 \mathrm{a}$ \\
P8 (10 hari) & $87.38 \mathrm{a}$ \\
\hline
\end{tabular}

Keterangan : HSBM (hari setelah bunga mekar). Angka - angka yang di ikuti huruf yang sama pada kolom yang sama tidak berbeda nyata uji Duncan $5 \%$.

Dari ketiga aspek yang diamati berdasarkan uji anova didapatkan hasil yang tidak berpengaruh nyata. Dimana lightness merupakan tingkat kecerahan buah dimana nilai 0 berarti gelap dan 100 berarti terang dari hasil rerata yang didapat pada semua perlakuan nilai L dibawah 50 sehingga dapat disimpulkan buah okra merah cenderung gelap.

Aspek selanjutnya yaitu a (redness) dimana jika nilai positif berarti berwarna merah jika negatif berarti berawana 
hijau. Dari hasil rerata yang didapat pada semua perlakuan semuanya bernilai positif yang artinya buah okra berwarna merah.

Aspek warna terakhir yaitu b (yellowness) dimana jika nilai yang didapat positif berarti berwarna kuning jika nilai yang didapat negatif berati berwarna biru. Dari hasil rerata yang didapat untuk semua perlakuan mendapat nilai positif artinya buah okra

memiliki warna kuning. Dapat disimpulkan bahwa buah okra memiliki tingkat kecerahan yang cenderung gelap dengan kombinasi warna merah dan kuning. Hasil yang di dapat pada variabel warna buah tidak berbeda nyata pada semua aspek, diduga dikarenakan rentan antar perlakuan yang terlalu pendek.

\section{Aktivitas Antioksidan Total Buah (\%)}

Analisis Aktivitas antioksidan total buah yang dilakukan mengunakan metode DPPH nilai aktivitas antioksidan total buah okra dapat dilihat pada Tabel 6. Hasil yang di dapat diketahui bahwa umur panen berpengaruh terhadap aktivitas antioksidan buah okra dimana semakin lama umur panen aktivitas antioksidan cenderung meningkat, dari data yang didapat perlakuan P5 memiliki nilai aktivitas antioksidan tertinggi namun tidak berbeda nyata dengan perlakuan P2, P3, P4, P6, P7, dan P8. Perubahan aktivitas antioksidan terhadap umur panen yang berbeda diduga karena perubahan senyawa kimia selama proses perkembangan buah.

Menurut Muchtadi et al. (2013) selama proses pematangan buah akan terjadi perubahan fisik dan kimia seperti perubahan kadar air, protein, lemak, asam organik, vitamin, mineral dan karbohidrat. Perubahan karbohidrat pati menjadi glukosa atau sebaliknya akan mempengaruhi aktivitas antioksidan buah. Dimana glukosa merupakan bahan dasar dari senyawa metabolit sekunder yang dapat berperan sebagai antioksidan, perubahan vitamin selama perkembangan buah juga mempengearuhi aktivitas antioksidan buah dimana beberapa vitamin juga berperan sebagai antioksidan, selanjutnya perubahan pigmen warna juga akan mempengaruhi aktivitas antioksidan buah dikeranakan beberapa pigmen bisa bertindak sebagai antioksidan. Pada umur panen 3 sampai 4 hari setelah bunga mekar glukosa cenderung di ubah menjadi senyawa yang bersifat antioksidan seperti vitamin c, qurcetin, antosianin, likopen, dan $\beta$-karoten. Pada umur panen 4 sampai 7 hari glukosa tidak hanya diubah menjadi senyawa antioksidan, glukosa juga diubah menjadi serat yaitu selulosa, hemiselulosa dan pektin, dimana aktivitas antioksidan tidak meningkat signifikan, sefangkan nilai hardness dan chewiness meninkat. diduga molekul glukosa saling berikatan melalui gugus B-glukosa dari molekul yang satu dengan gugus hidroksil C2, C3 menjadi hemiselulosa, berikatan dengan gugus hidroksil $\mathrm{C} 4$ menjadi selulosa dan berikata dengan asam D-galakturonat, menjadi pektin. Pada umur panen 6 sampai 10 hari setelah bunga mekar glukosa cendrung di ubah menjadi serat, terlihat dari nilai aktivitas antioksidan yang menurun dan nilai hardness, fractrurability dan chewiness yang meningkat. Tektur yang keras juga dipengaruhi oleh kadar air buah, dimana pada umur panen 6 - 10 hari setelah bunga mekar memiliki nilai kadar air yang relatif menurun.

\section{KESIMPULAN}

a. Umur panen buah okra yang berbeda pada interval pengamatan tiga hari setelah bunga mekar sampai sepuluh hari setelah buah mekar berpengaruh nyata terhadap aktivitas antioksidan total buah, panjang buah, diameter buah, bobot basah buah, bobot kering buah, kadar air buah, dan tekstur buah okra merah. Namun, tidak berpengaruh nyata terhadap variabel pengamatan warna buah okra merah.

b. Umur panen buah okra merah 6 hari setelah bunga mekar merupakan perlakuan terbaik untuk sayur dengan nilai aktivitas antioksidan total $87.05 \%$, panjang buah 12.22 $\mathrm{cm} /$ buah, diameter buah $1.19 \mathrm{~cm} /$ buah, bobot basah buah $18.61 \mathrm{~g} / \mathrm{buah}$, bobot kering buah $1.17 \mathrm{~g} / \mathrm{buah}$, kadar air buah 90.87\%/buah, warna buah (L 13.90; a 4.30; b 15.48), dan tekstur buah (kekerasan $362.25 \mathrm{~g} /$ buah; daya patah $438.93 \mathrm{~g} /$ buah; kealotan 5.47).

\section{DAFTAR PUSTAKA}

Adetuyi, F.O. A.U, Osagie. A.T, Adekunle. 2008. Effect of Postharvest Storage Techniques on the Nutritional Properties of Benin Indigenous Okra Abelmoschus esculentus (L) Moench. Pakistan. Paskistan Journal Nutrition. 7(5):652.

Antarlina, S.S. 2003. Identifikasi Sifat Fisik dan Kimia Buah-Buahan Lokal Kalimantan. Banjarbaru. Balai Penelitian Pertanian Lahan Rawa. Hal. 80-81.

Cahyadi, W. 2006. Analisis Dan Aspek Kesehatan Bahan Tambahan Pangan. Jakarta. Bumi Aksara. Hal. 134157.

Haliza, W.S.I, S. Kailaku, Yuliatin. 2012. Penggunaan Mixture Response Surface Methodology Pada Optimasi Formula Brownies Berbasis Tepung Talas Banten (Xanthosoma undipes K. Koch) Sebagai Alternatif Pangan Sumber Serat. Bogor. J. Pascapanen. 9(2):98-103.

Hariyani, E., Widaryanto, N. Herlina. 2012. Pengaruh Umur Panen Terhadap Rendemen dan Kualitas Minyak Atsiri Tanaman Nilam (Pogostemon cablin Benth.). Malang. Jurnal Protan. 3(3):208-211

Hidayat, Y. 2010. Perkembangan Bunga dan Buah pada Tegakan Benih Surian (Toona sinensis Roem). Sumedang. Jurnal Agrikultura. 21(1):15-16

Ikrawati, N.A., Rokhmah. 2016. Budidaya Okra Dan Kelor Dalam Pot. Jakarta. Balai Pengkajian Teknologi Pertanian (BPTP) Jakarta. 
Katno, D., Subositi, R. Mujahid. 2006. Inventarisasi Tanaman Obat Indonesia (IV). Jakarta. Departemen Kesehatan Badan Peneitian Dan Pengembngan Kesehatan. 2-3.

Lintang, J.A., H. Rusmarllin, L.M. Lubis. 2014 Aktivitas Antioksidan Ekstrak Umbi Bengkoang Pada Berbagai Umur Panen Dengan Metode Dpph (2,2-diphenyl-1picrylhydrazyl). Medan. Jurnal Rekayasa Pangan dan Pertanian.2(1):53-55.

Maliluan, C., Y.B. Pramono, B. Dwiloka. 2013. Physical and Sensory Characteristics of Chicken Nuggets With Utilization Rice Bran to Substitute Wheat Flour. Jurnal Aplikasi Teknologi Pangan 2(2):72-74.

Muchtadi, T.R., Sugiyono, F. Ayustaningwarno. 2013. Ilmu Pengetahuan Bahan Pangan. Bandung. Alfabeta. 146182.

Muchtadi, T.R., Sugiyono. 2014. Prinsip dan Proses Teknologi Pangan. Bandung. Alfabeta. 54-56.

Mujiono, L. Afandi, L. Maknun, B. Noriandita, W. Lestari. U. Purwadari. 2010. Optimasi Disintegrasi Partikel Protein Dengan Kombinasi Perlakuan Enzimatik Dan Fisik Pada Pembentukan Tekstur Keju Vegetarian Kacang Komak Madura. Bangkalan Universitas Trunojoyo Madura.

Mutiarawati, T. 2007. Penanganan Pasca Panen Hasil Pertanian. Bandung. Universitas Padjadjaran. 1-5.

Nurhayati, S. 2004. Kajian Sifat Fisik, Kimia dan Fisiologi Terhadap Beberapa Tingkat Kematangan Buah Rambutan Varietas Si Macan di Kabupaten Gunung Kidul Yogyakarta. Tanggerang. Jurnal Matematika Sains dan Teknologi 5(2):8-94.

Oliviera, F.D., A. Mugridge, A.R. Chaves, R.H. Mascheroni, S.Z. Vina. 2012. Quality Attributes of Okra (Abelmoschus esculentus L. Moench) Pods as Affected by Cultivar and Fruit Size. Buenos Aires. Journal of Food Research. 1(4):224-233.

Prabhune, A., M. Sharma, B. Ojha. 2017. Abelmoschus esculentus (Okra) potential natural compound for prevention and management of Diabetes and diabetic induced hyperglycemia. Tamil Nadu. International Journal of Herbal Medicine. 5(2):66-68.

Ramadhan, P. 2015. Mengenal Antioksidan. Yogyakarta. Graha Ilmu.

Rukmana, R., H. Yudirachman. 2016. Budidaya Sayuran Lokal. Yogyakarta. Kanisius.

Sayuti. K., R. Yenrina. 2015. Antioksidan Alami Dan Sintetik. Padang. Andalas University Press.7-73.

Sengkal, B.C., M. Kiralan, C. Yaman. 2014. The effect of different harvest stages on chemical composition and antioxidant capacity of essential oil from Artemisia аппиа L. Mudurnu. Journal of Agricultural Sciences 21. 74-76.

Tripathi, K.K., R. Warrier, V. Ahuja, O.P. Govil. 2011. Biology Of Abelmoschus esculentus L. (Okra). New Delhi. Department of Biotecnologogy Government of India.

United States Department of Agriculture. 1997. United States Standards for Grades of Okra for Processing 11278, Okra, raw. Washington, D.C. U.S. Department Of Agriculture.

United States Department of Agriculture. 2016. Full Report (All Nutrients) 11278, Okra, raw. Washington, D.C. U.S. Department Of Agriculture.

Utama, I.M.S., N.S. Antara. 2013. Pasca Panen Tanaman Tropika: Buah Dan Sayur. Denpasar. Universitas Udayana. 8-9.

Warsito, H., Rindiani, F. Nurdyansyah. 2015. Ilmu Bahan Makanan Dasar. Yogyakarta. Nuha Medika:237-243.

Winarsi, H. 2007. Antioksidan Alami dan Radikal Bebas. Yogyakarta. Kanisius.

Winarti, S. 2016. Makanan Fungsional. Yogyakarta (ID): Graha Ilmu.

Womdim, R.N., C. Ojiewo, M. Abang, M.O. Oluoch. 2009. Proceedings of a Tecnical Consultation Workshop Held in Arusha. Tanznia. Scripta Horticulturae $15: 175$. 